\title{
Energy Systems Environmental Restoration Program ORNL Environmental Restoration Program \\ Inactive Tanks Remediation Program Batch I, Series I Tanks 3001-B, 3004-B, 3013, and T-30 \\ Technical Memorandum
}

Date Issued-May 1995

Prepared by

H\&R Technical Associates, Inc.

151 Lafayette Drive

Oak Ridge, Tennessee 37831-4159

Prepared for

U.S. Department of Energy

Office of Environmental Restoration and Waste Management under budget and reporting code EW 20

Environmental Restoration and Waste Management Program

Oak Ridge National Laboratory

Oak Ridge, Tennessee 37831-6285

managed by

MARTIN MARIETTA ENERGY SYSTEMS, INC.

for the

U.S. DEPARTMENT OF ENERGY

under contract DE-AC05-84OR21400

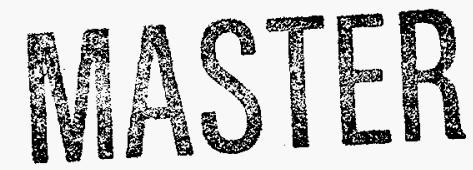


This report has been reproduced directly from the best available copy.

Available to DOE and DOE contractors from the Office of Scientific and Technical Information, P.O. Box 62, Oak Ridge, TN 37831; prices available from 615-576-8401 (fax 615-576-2865).

Available to the public from the National Technical Information Service, U.S. Department of Commerce, 5285 Port Royal Rd., Springfield, VA 22161.

\section{DISCLAIMER}

This report was prepared as an account of work sponsored by an agency of the United States Government. Neither the United States Government nor any agency thereof, nor any of their employees, makes any warranty, express or implied, or assumes any legal liability or responsibility for the accuracy, completeness, or usefulness of any information, apparatus, product, or process disclosed, or represents that its use would not infringe privately owned rights. Reference herein to any specific commercial product, process, or service by trade name, trademark, manufacturer, or otherwise does not necessarily constitute or imply its endorsement, recommendation, or favoring by the United States Government or any agency thereof. The views and opinions of authors expressed herein do not necessarily state or reflect those of the United States Government or any agency thereof. 


\section{DISCLAIMER}

Portions of this document may be illegible in electronic image products. Images are produced from the best available original document. 


\section{PREFACE}

This Inactive Tanks Remediation Program Batch I, Series I Tanks 3001-B, 3004-B, 3013, and T-30 Technical Memorandum at ORNL was written to provide information that can be used by Environmental Restoration Program management to make decisions concerning the disposition of four inactive tank systems that have been designated Batch I, Series I, by the Inactive Tanks Remediation Program team. The document includes historical information as well as information from recent site investigations. The work was performed in March 1995 by H\&R Technical Associates, Inc., under subcontract no. 32X-AQG67C. 


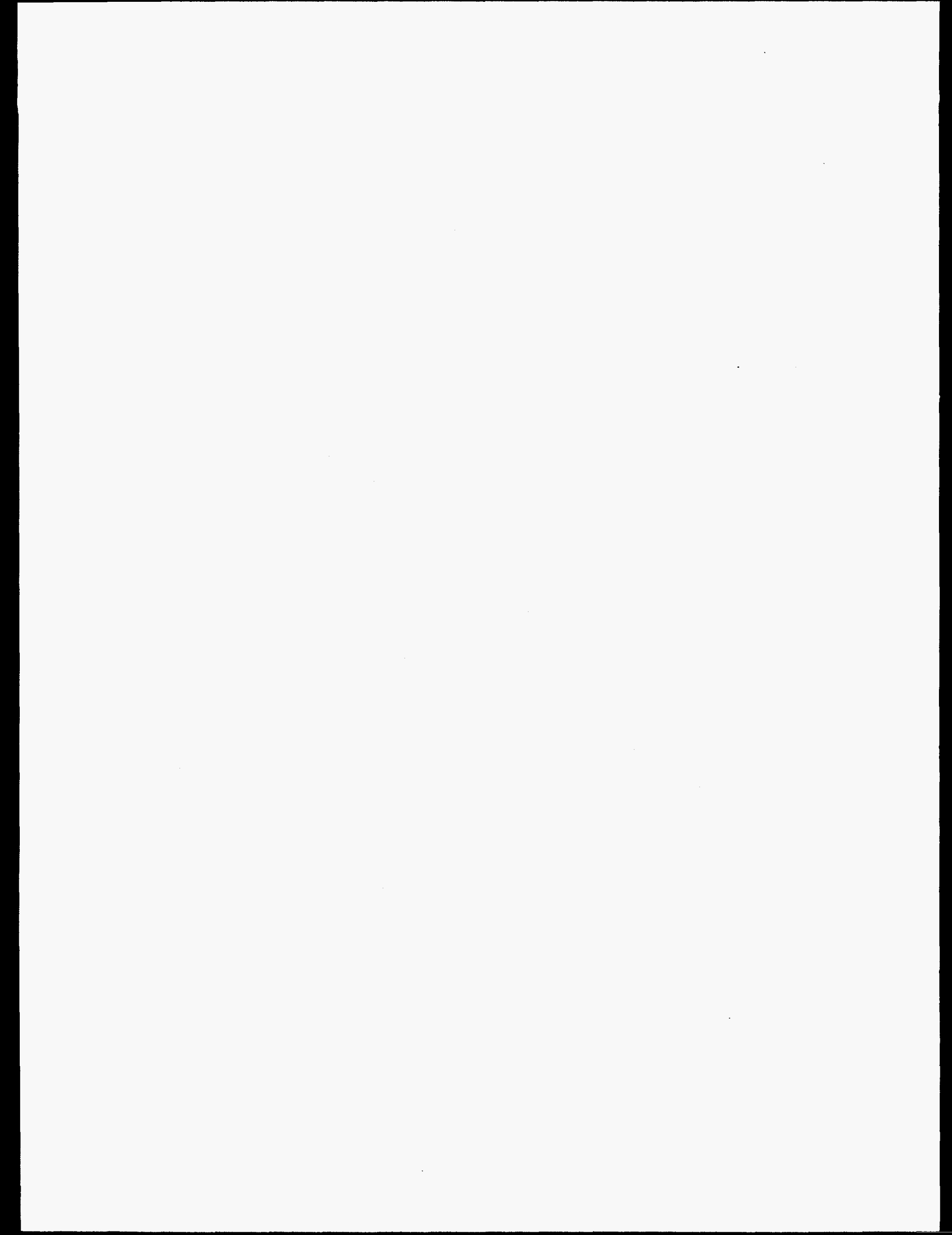




\section{CONTENTS}

TABLES $\ldots \ldots \ldots \ldots \ldots \ldots \ldots \ldots \ldots \ldots \ldots \ldots \ldots \ldots \ldots \ldots \ldots \ldots \ldots$

FIGURES $\ldots \ldots \ldots \ldots \ldots \ldots \ldots \ldots \ldots \ldots \ldots \ldots \ldots \ldots \ldots \ldots$ vii

ABBREVIATIONS $\ldots \ldots \ldots \ldots \ldots \ldots \ldots \ldots \ldots \ldots \ldots \ldots \ldots \ldots \ldots \ldots \ldots \ldots$

EXECUTIVE SUMMARY $\ldots \ldots \ldots \ldots \ldots \ldots \ldots \ldots \ldots \ldots \ldots \ldots \ldots \ldots \ldots$

1. INTRODUCTION $\ldots \ldots \ldots \ldots \ldots \ldots \ldots \ldots \ldots \ldots \ldots \ldots \ldots \ldots \ldots \ldots \ldots$

2. INACTIVE TANKS REMEDIATION PROGRAM $\ldots \ldots \ldots \ldots \ldots \ldots \ldots \ldots \ldots$

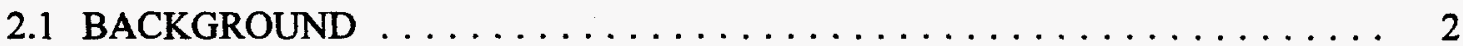

2.2 SELECTION OF TANKS FOR CURRENT REMEDIATION $\ldots \ldots \ldots \ldots \ldots .3$

3. BATCH I, SERIES I TANK SYSTEMS $\ldots \ldots \ldots \ldots \ldots \ldots \ldots \ldots \ldots \ldots$

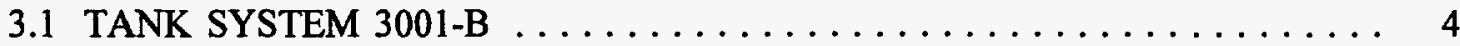

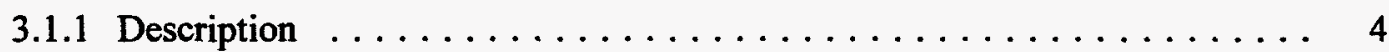

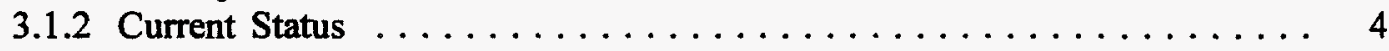

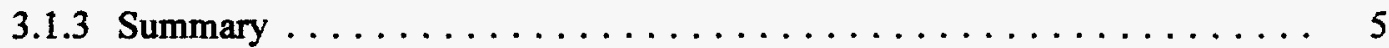

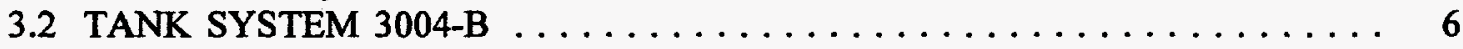

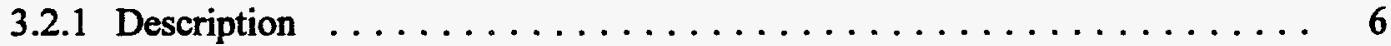

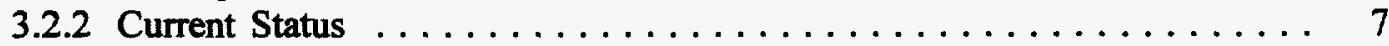

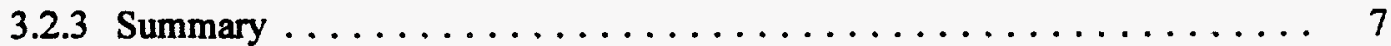

3.3 TANK SYSTEM $3013 \ldots \ldots \ldots \ldots \ldots \ldots \ldots \ldots \ldots \ldots \ldots$

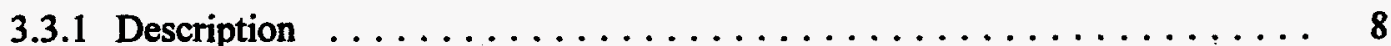

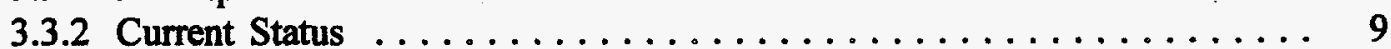

3.3 .3 Summary $\ldots \ldots \ldots \ldots \ldots \ldots \ldots \ldots \ldots \ldots \ldots \ldots \ldots$

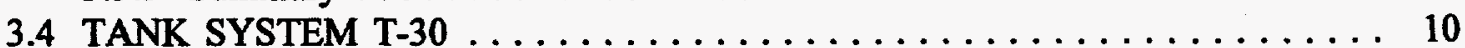

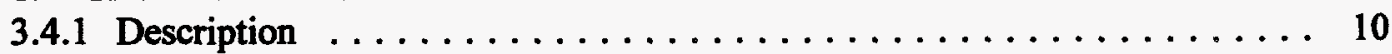

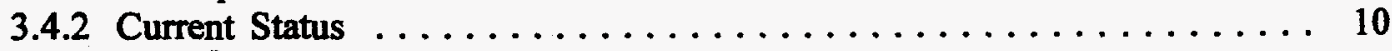

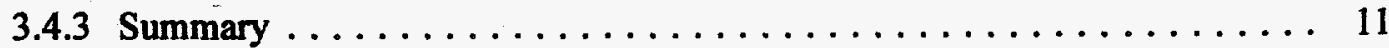


TABLES

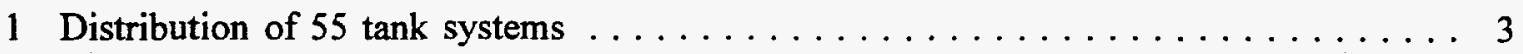

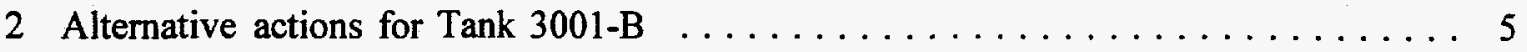

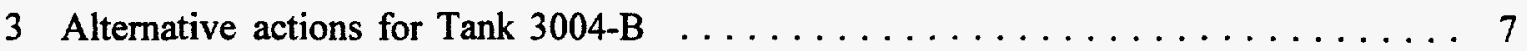

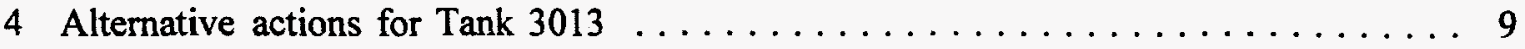

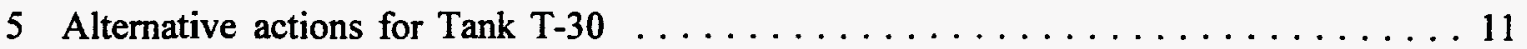

\section{FIGURES}

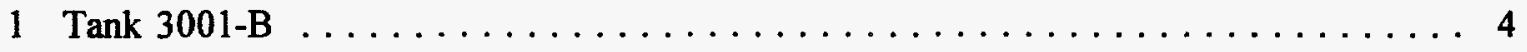

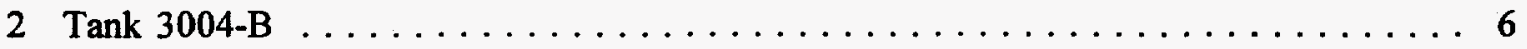

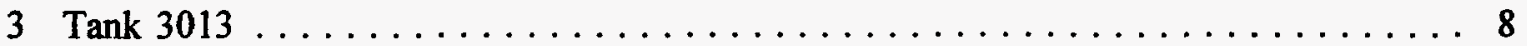

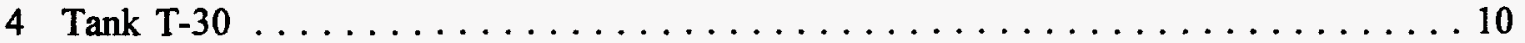




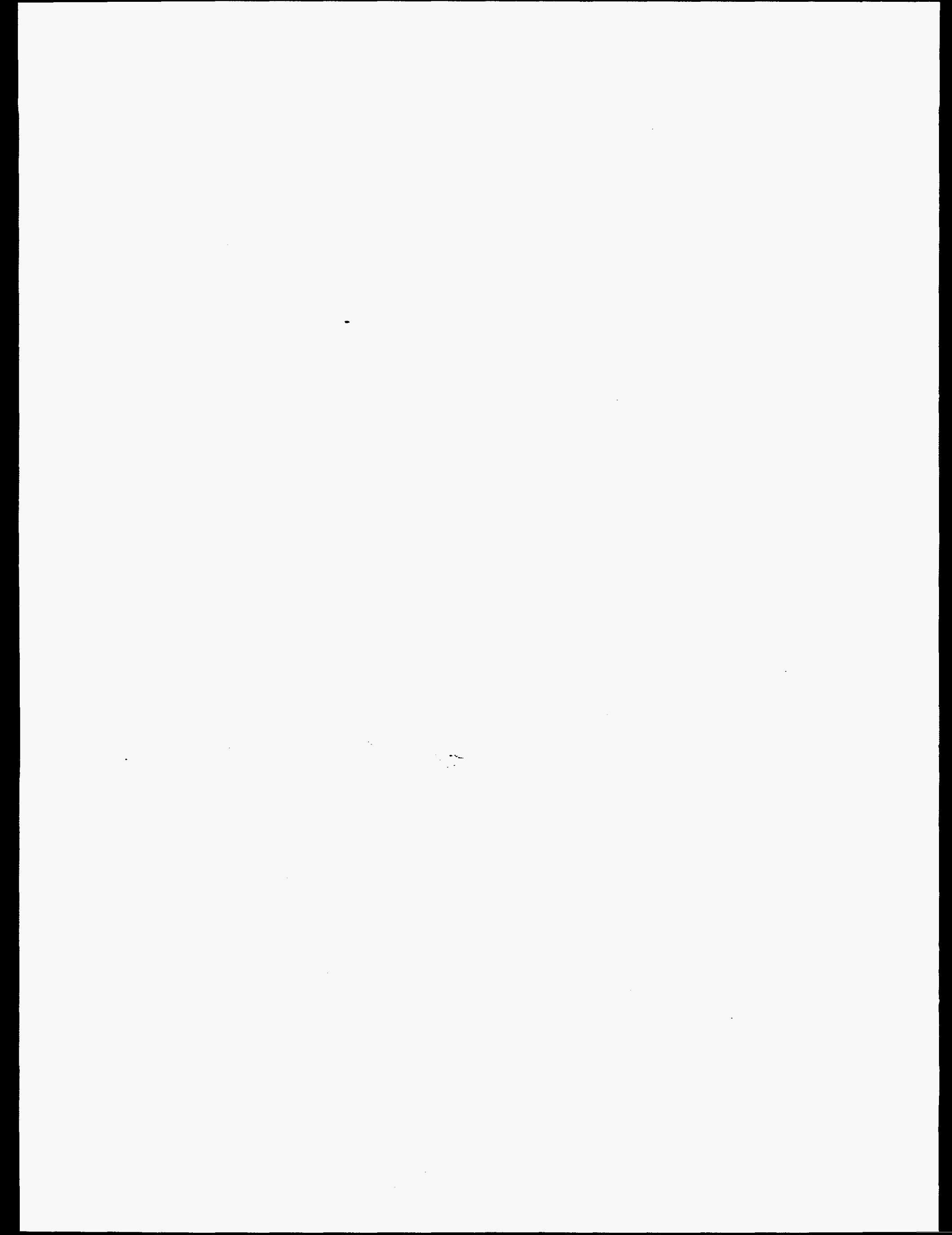




\section{ABBREVIATIONS}

CERCLA Comprehensive Environmental Response, Compensation, and Liability Act EPA

FFA U. S. Environmental Protection Agency

GAAT

LLLW

Federal Facility Agreement

ORNL

OU

Gunite and Associated Tanks

liquid low-level waste

Oak Ridge National Laboratory

operable unit

TDEC

Tennessee Department of Environment and Conservation

WAG

waste area grouping 



\section{EXECUTIVE SUMMARY}

This technical memorandum provides information that can be used to make decisions concerning the disposition of four inactive tank systems that have been designated Batch I, Series I, by the Inactive Tanks Remediation Program team. The Batch I, Series I, tanks are 3001-B, 3004-B, 3013, and T-30. The report offers viable alternatives for tank system disposition.

The Comprehensive Environmental Response, Compensation, and Liability Act (CERCLA) requires a Federal Facility Agreement (FFA) for federal facilities placed on the National Priorities List. The Oak Ridge Reservation was placed on that list on December 21, 1989, and the agreement was signed in November 1991 by DOE's Oak Ridge Operations Office, the U. S. Environmental Protection Agency-Region IV, and the Tennessee Department of Environment and Conservation. The effective date of the FFA is January 1, 1992. One objective of the FFA is to ensure that inactive liquid low-level radioactive waste tank systems are evaluated and, if appropriate, remediated through the CERCLA process. The Inactive Tanks Remediation Program and the Gunite and Associated Tanks Project (GAAT) are the two efforts that will meet this FFA objective. This memorandum addresses tank systems within the Inactive Tanks Remediation Program. Separate CERCLA documentation addresses the tank systems within the GAAT Project.

This technofal memorandum presents background information concerning the Inactive Tanks Remedistion Program and explains how the inactive tanks were selected for disposition. It also describes the physical characteristics of each of the four Batch I, Series I, tank systems; summarizes the present status of each system; presents alternatives for disposition of each tank system along with the merits and liabilities of each alternative; and summarizes information affecting future actions concerning each tank system. 


\section{INTRODUCTION}

This technical memorandum provides information that can be used to make decisions concerning the disposition of the four inactive tank systems that have been designated Batch I, Series I by the Inactive Tanks Remediation Program team. The Batch I, Series I tanks are 3001-B, 3004-B, 3013, and T-30. The report offers viable alternatives for tank system disposition.

The information in this memorandum is presented in three chapters. Chapter 2, Overview of Inactive Tanks Remediation Program, presents background information concerning the Inactive Tanks Remediation Program and explains how the inactive tanks were selected for disposition. Chapter 3, Discussion of Individual Batch I Series I Tank Systems, describes the physical characteristics of each of the four Batch I, Series I tank systems; summarizes the present status of each system; presents alternatives for disposition of each tank system along with the merits and liabilities of each alternative; and summarizes information affecting future actions concerning each tank system. 


\section{INACTIVE TANKS REMEDIATION PROGRAM}

\subsection{BACKGROUND}

Comprehensive Environmental Response, Compensation, and Liability Act (CERCLA) requires an Federal Facility Agreement (FFA) for federal facilities placed on the National Priorities List. The Oak Ridge Reservation was placed on that list on December 21, 1989, and the agreement was signed in November 1991 by DOE's Oak Ridge Operations Office, the U.S. Environmental Protection Agency (EPA) Region IV, and the Tennessee Department of Environment and Conservation (TDEC). The effective date of the FFA is January 1, 1992. One objective of the FFA is to ensure that inactive liquid low-level waste (LLLW) tank systems are evaluated and, if appropriate, remediated through the CERCLA process. The Inactive Tanks Remediation Program and the Gunite and Associated Tanks Project (GAAT) are the two efforts that will meet this FFA objective. This memorandum addresses tank systems within the Inactive Remediation Program. Separate CERCLA documentation addresses the tank systems within the GAAT Project. (Note: In the FFA and other documents, the inactive LLLW tank systems are also referred to as "removed-from-service" tank systems. These terms can be used interchangeably. For consistency, the term "inactive" is used in this memorandum.)

The LLLW system was installed in the 1940s and periodically expanded and upgraded to support Oak Ridge National Laboratory (ORNL) and its variety of research activities. The entire system and its modifications were designed to minimize radiation exposure to LLLW system users and operators. To minimize exposure, the system includes features such as unvalved, gravity-drained transfer lines to prevent waste backup into generator areas; shielded lines and tanks; and provisions for remote operations.

The LLLW system is a complex system with multiple facilities, users, and operators. The system is used for collection, neutralization, transfer, and concentration of aqueous radioactive waste solutions from generator facilities throughout ORNL. These generator facilities include research and development laboratories, nuclear reactors, radioisotope production facilities, and process waste treatment plants.

Two major pathways exist for the transfer of wastes from the source to the LLLW system. One pathway consists of accumulating the liquid wastes in holding tanks located in the source buildings and then discharging the wastes from these holding tanks to below-grade collection tanks, which serve several different source buildings. The second pathway is to discharge the LLLW through sinks and drains that are connected directly to the below-grade collection tanks by unvalved piping. A network of below-grade piping interconnects the various system components.

Over the years, tank systems were removed from service as their integrity was breached or as programs were terminated. New tank systems installed during the past 10 to 15 years incorporate secondary containment and improved leak detection features. The LLLW system is thus a mix of singly and doubly contained tank systems. The portions of the system that have been declared inactive consist almost exclusively of tank systems without secondary containment. To date, 55 tank systems have been deactivated.

These 55 inactive LLLW tank systems are distributed among four waste area groupings (WAGs). WAGs are contaminated areas that are either geographically contiguous or 
hydrologically confined units. Each WAG can be further divided into operable units (OUs). These OUs are smaller, more manageable units chosen on the basis of contaminant pathways analysis, application of similar remediation technology, geographical consideration, assessment of early or time-phased action, and remediation efficiency or simplicity considerations. The distribution of all 55 tank systems is given in Table 1.

Table 1. Distribution of 55 tank systems

\begin{tabular}{lc}
\hline \multicolumn{1}{c}{ Location } & Number of LLLW tanks \\
\hline WAG 1 , OU 1 & 18 \\
WAG 1 , OU 10 & 28 \\
WAG 5 & 6 \\
WAG 8 & 1 \\
WAG 9 & 2 \\
\hline
\end{tabular}

As previously stated, all the inactive tank systems are being remediated either under the Inactive Tanks Remediation Program or GAAT Project. The Inactive Tanks Remediation Program includes those 37 tanks in WAG 1 OU 10, WAG 5, WAG 8, and WAG 9. The GAAT Project includes the 18 tanks in WAG 1 OU 1 , which were grouped together owing to the size of the tanks and complexity of their cleanup.

\subsection{SELECTION OF TANKS FOR CURRENT REMEDIATION}

The 37 tanks within the Inactive Tanks Remediation Program were preliminarily screened to prioritize the tanks for remediation. This screening considered risk, remediation technologies, interferences with other piping and equipment, location, sludge removal techniques, and storage requirements. On the basis of this preliminary screening, the tanks were assigned to one of five "batches" for consideration of interim remedial action. Batch I tanks would undergo interim remediation first. The Batch I tanks are 3001-B, 3004-B, 3013, and T-30 (Series I), H-209 and WC-1 (Series II), and W-19 and W-20 (Series III). The final remediation of each tank site will be completed during the final remediation of the WAG containing the tank system. The batch designation may or may not be applicable for final remediations. 


\section{BATCH I, SERIES I TANK SYSTEMS}

\subsection{TANK SYSTEM 3001-B}

\subsubsection{Description}

Tank 3001-B is an 2300 -gal stainless steel tank located in a concrete vault under the outside stairway landing adjacent to the south wall of Building 3001 . System piping (see Fig. 1) consists of a 3-in. stainless steel header that served a sink and a floor drain in a hot lab in Building 3001 and a 2-in. stainless steel discharge line with isolation valve that connects to a 2-in. stainless steel header running from Building 3019 to tank WC-19. The hot lab equipment was removed around 1965 and the area now houses a demineralizer. Visual inspection of the area revealed that the two drains to tank 3001-B have been sealed.

\subsubsection{Current Status}

Tank 3001-B was examined in 1993 and found to be empty. The tank was inspected by video camera in January 1995 and found to be empty. This tank is categorized as an industrial facility. ${ }^{1}$ Table 2 shows the alternative actions for Tank 3001-B.

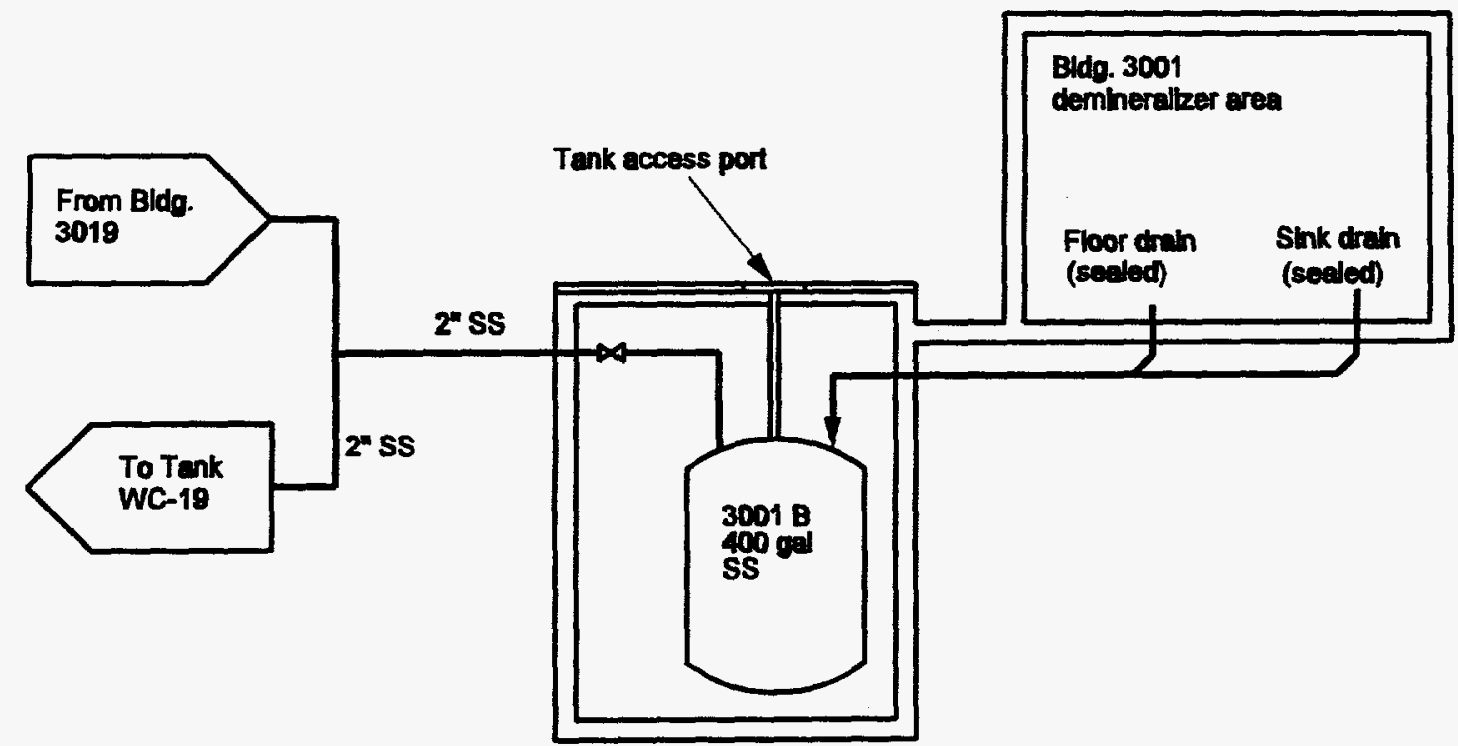

Fig. 1. Tank 3001-B.

\footnotetext{
${ }^{1}$ The safety assessment Project Safety Assessment Inactive Tanks Remediation Program, ORNL/ENG/SA- 2390/R0 categorizes this tank as an "Industrial Facility" in accordance with the requirements of Hazard Baseline Documentation, DOE-EM-STD-5502-94, and Nuclear Hazard Categorization Criteria for ORNL Waste Management and Remedial Action Division Facilities, ORNL/WMRAD/AD-109/R0.
} 
Table 2. Alternative actions for Tank 3001-B

\begin{tabular}{|c|c|}
\hline Alternative & Result \\
\hline Leave as is. & $\begin{array}{l}\text { Field investigation has found that the inlets to the tank that } \\
\text { are shown on engineering drawings have been sealed. No } \\
\text { contamination is likely to enter the tank through its } \\
\text { engineered system piping. Risk from the tank has been shown } \\
\text { to be below the EPA target risk range and does not exceed a } \\
10^{-6} \text { risk level. }\end{array}$ \\
\hline Cut and cap inlet and outlet lines. & $\begin{array}{l}\text { Cutting and capping the inlet line would not significantly } \\
\text { reduce the probability of liquid entering the tank because the } \\
\text { inlet openings to this line are already sealed and the piping is } \\
\text { inside Building } 3001 \text {. Cutting and capping the outlet line } \\
\text { would eliminate the remote possibility of back flow through } \\
\text { the discharge line that is connected to the active system. Risk } \\
\text { from the tank would not be increased by selection of this } \\
\text { alternative, but any further risk reduction it provides would } \\
\text { require careful cost justification. }\end{array}$ \\
\hline Remove tank. & $\begin{array}{l}\text { Removing the tank would totally eliminate any future risk } \\
\text { from the tank. }\end{array}$ \\
\hline Fill tank with grout. & $\begin{array}{l}\text { Risk from the tank would not be increased by selection of } \\
\text { this alternative, but any further risk reduction it provides } \\
\text { would require careful cost justification. Filling the tank with } \\
\text { grout would be detrimental if, in the future, a decision is } \\
\text { made to remove the tank as part of an overall site remedial } \\
\text { action. }\end{array}$ \\
\hline
\end{tabular}

\subsubsection{Summary}

Field investigation in January 1995 shows that the inlet drains to this tank depicted on engineering drawings are sealed and that the tank has remained empty since the last examination. Thus, there is every indication that the tank is secure from receiving input through the engineered inlet piping system. Little possibility exists for the inflow of groundwater or surface water into the tank as a result of the tanks location in a concrete vault. This possibility is further lessened by the concrete pad over the vault and the fact that the surrounding paved area slopes away from the vault. Because the discharge line connects to the active LLLW system via a header to active tank WC-19, a remote possibility exists that back flow from this line could enter tank 3001-B. For this reason, consideration should be given to isolating the discharge line from 3001-B. This could be accomplished by excavating just south of the 3001-B vault to locate, cut, and cap the discharge line before it connects to the inlet line for WC-19. Cutting and capping the discharge line outside the vault would require excavating to a depth of -8-10-ft. Tank 3001-B and its associated piping, thus secured from the probability of receiving further contamination and having been shown to pose no unacceptable risk, could be left in place until final remedial action is accomplished for Building 3001. Another alternative is to remove the tank from the vault. The top of the vault is located $\sim 21 / 2 \mathrm{ft}$ below the surface of the asphalt parking area. By removing the outside steel stairs to the second floor of Building 3001 and the concrete stair landing and excavating to allow removal of the vault covers, the 
tank could be removed and the piping isolated within the vault. EPA and TDEC have agreed that this tank need not be remediated through the CERCLA process.

\subsection{TANK SYSTEM 3004-B}

\subsubsection{Description}

Tank 3004-B is an $\sim 100$-gal stainless steel tank located in a vault just east of Building 3008. System piping (see Fig. 2) consists of a 2-in. stainless steel inlet header that served three drains in Building 3005 and a 2-in. stainless steel discharge line running $\sim 95 \mathrm{ft}$ to a valve box near Building 3001 where it joins a header going to active tank WC-19. The $200-\mathrm{ft}$ length of the inlet piping includes about $80 \mathrm{ft}$ of buried piping and about $120 \mathrm{ft}$ of piping either underneath or embedded within the base slab of Building 3005. In addition, a $11 / 2$-in. stainless steel line vents the tank to the off-gas system. The tank was installed in 1956 to serve the Low Intensity Test Reactor in Building 3005 and was removed from service in the late 1960s. Building 3005 is now used as a machine shop, and visual inspection shows that all three drains from that building to tank 3004-B have been sealed.

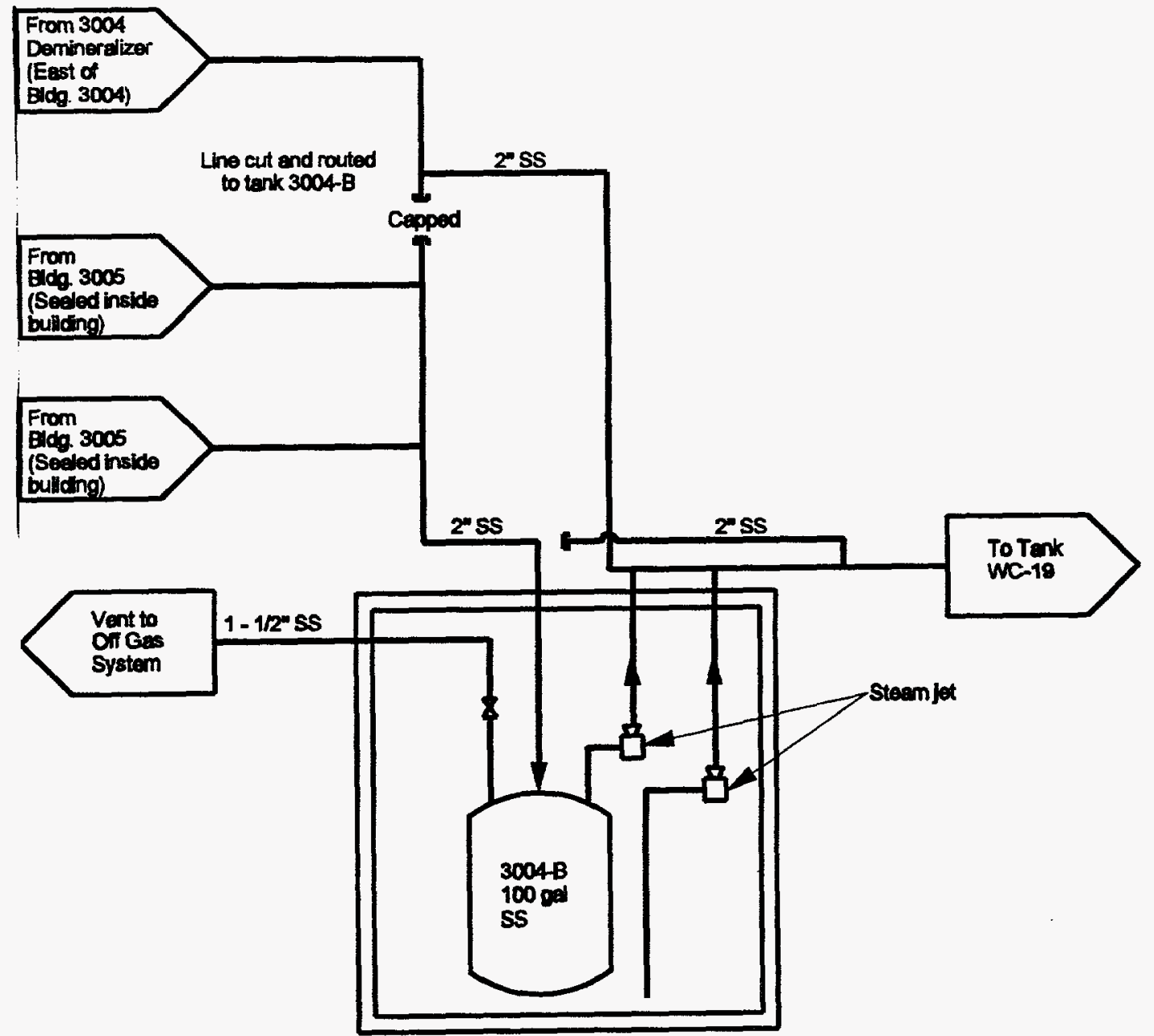

Fig. 2. Tank 3004-B. 


\subsubsection{Current Status}

Tank 3004-B is categorized as an industrial facility (see footnote 1). The tank was emptied in 1993 and was found to be full of ater when examined in January 1995. A field screening survey at that time indicated no rad.ative content in the water. The water is thought to be condensate from the steam line sering the tank discharge steam jet. Table 3 shows the alternative actions for Tank 3004-B.

Table 3. Alternative actions for Tank 3004-B

\begin{tabular}{ll}
\hline \multicolumn{1}{c}{ Alternative } & \multicolumn{1}{c}{ Result } \\
\hline Leave as is. & $\begin{array}{l}\text { Field investigation has found that the inlets to the tank that are } \\
\text { shown on engineering drawings have been sealed. No } \\
\text { contamination can likely enter the tank through its engineered } \\
\text { system piping. Risk from the tank has been shown to be below } \\
\text { the EPA target risk range and does not exceed a } 10^{-6} \text { risk level. }\end{array}$ \\
Cut and cap inlet, outlet, and & $\begin{array}{l}\text { Cutting and capping the inlet line would not significantly } \\
\text { off-gas vent lines. }\end{array}$ \\
reduce the probability of liquid entering the tank because the \\
inlets to this line have been shown to be sealed. Cutting and \\
capping the outlet line would eliminate the remote possibility \\
of back flow through the discharge line that is connected to the \\
active system. Isolating the off-gas vent line would eliminate \\
the possibility of contaminated condensate from the vent \\
system entering the tank. Risk from the tank would not be \\
increased by selection of this alternative, but any further risk \\
reduction it provides would require careful cost justification.
\end{tabular}

\subsubsection{Summary}

Field investigation shows that the drain lines from Building 3005 to tank 3004-B have been sealed. Thus, there is every indication that the tank is secure from receiving input through the engineered inlet piping system. The tank was emptied in 1993, and when examined again in January 1995, was found to contain liquid. The facility manager for the tanks suspects that the liquid is condensate from the steam line served the discharge jet on the tank. The steam line should be isolated from the tank and sisak level should be monitored for a period of time to verify that this is indeed the sours of liquid inflow to tank. If the source of inflow is identified and eliminated, future surveillance and maintenan. requirements would be minimal. Because the discharge line connects to the active LLLW system via an inlet line to active tank WC-19, a remote possibility exists that back flow from this line could enter tank 3004-B. For 
this reason, consideration should be given to isolating the discharge line from 3004-B. This could be accomplished within the vault containing the tank and would require no excavation. If this alternative is chosen, the inlet line and the off-gas vent line should also be cut and capped within the tank vault. This would involve little additional expense and would ensure that the tank and its associated piping, thus secured from the probability of receiving further contamination and having been shown to pose no unacceptable risk, could be left in place until final remedial action is accomplished for Building 3001 and the surrounding area or until the tank could be removed and disposed of if economically feasible. EPA and TDEC have agreed that this tank need not be remediated through the CERCLA process.

\subsection{TANK SYSTEM 3013}

\subsubsection{Description}

Tank 3013 is an $\sim 400$-gal tank that is buried just south of Building 3013 . System piping (see Fig. 3) consists of a 2-in. stainless steel inlet line from the cell beneath the floor of Building 3013, a 2-in. stainless steel vent to the off-gas system, and a 2-in. stainless steel discharge line that is cut and capped $\sim 50 \mathrm{ft}$ south of the tank. The inlet line is about $17 \mathrm{ft}$ in length from the cell connection to the tank inlet connection. Of this $17 \mathrm{ft}, \sim 8 \mathrm{ft}$ are underneath Building 3013. The off-gas line runs approximately $5 \mathrm{ft}$ vertically and $5 \mathrm{ft}$ horizontally and then ties to the 2-in. off-gas vent line from the cell. Four spare nozzles in the tank head and two connections to the tank jacket are closed with blind flanges located above grade. In addition, two 1/4-in. instrumentation lines run from the tank to Building 3013 and are terminated with caps just above the floor of Building 3013. The nominal 3-ft, 10-in. diameter head and all the connections except the two tank jacket connections are constructed with flanged and gasketed connections below grade. The discharge steam jet is above ground and the steam supply to it has been removed.

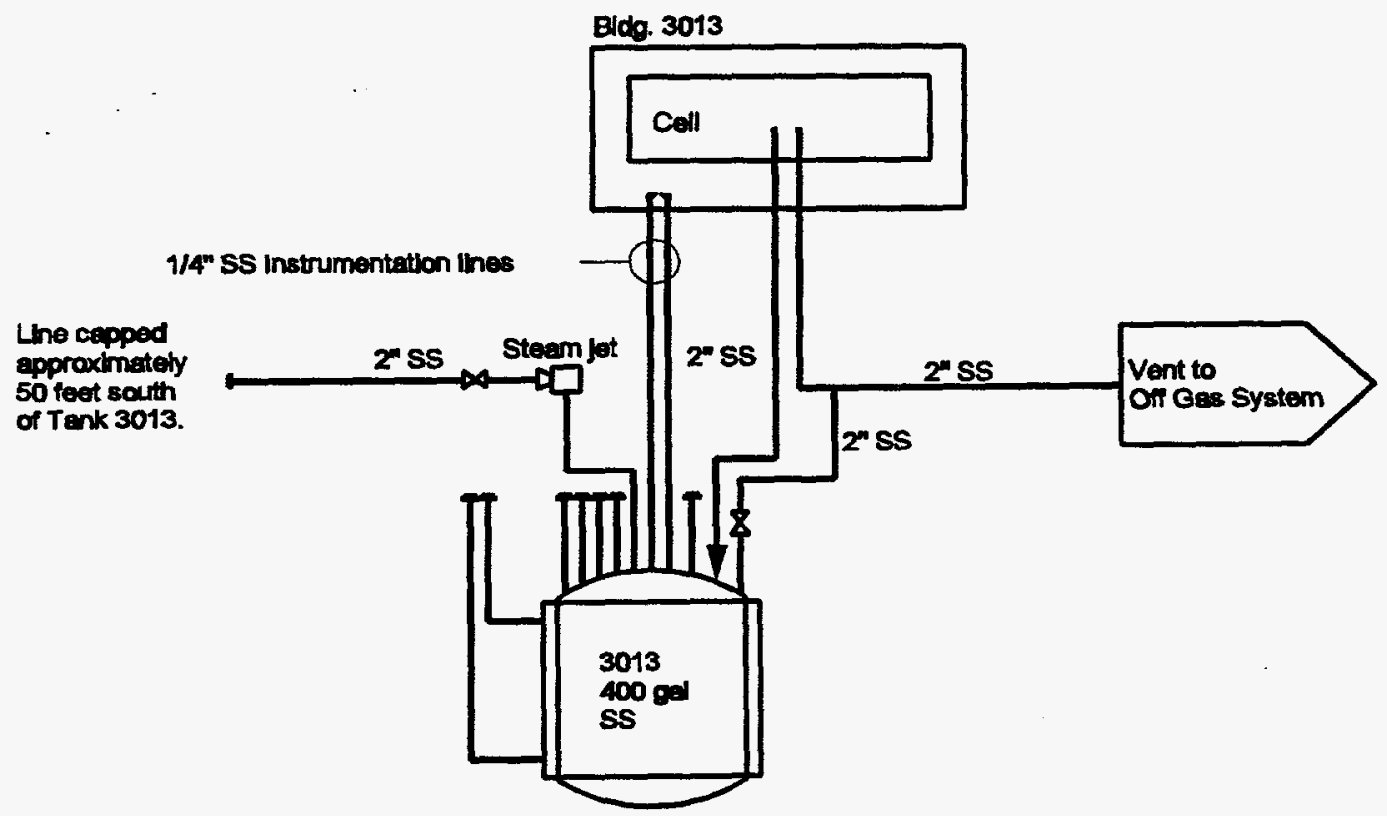

Fig. 3. Tank 3013. 


\subsubsection{Current Status}

Tank 3013 is categorized as an industrial facility (see footnote 1). The tank was emptied in 1993 and, when examined in January 1995, was founc contain $\sim 216$ gal of liquid. The facility manager conducting the examination noted that the gaskets in the above-ground flanges of the system piping appeared to have deteriorated and it is assumed that the gaskets in the underground flanges have suffered some degradation of their ability to seal. The liquid now in the tank likely came from rainfall or groundwater entering the tank through one or more of the seven flanges or through the joint of the tank head owing to degraded gaskets. Table 4 shows the alternative actions for Tank 3013.

Table 4. Alternative actions for Tank 3013

\begin{tabular}{ll}
\hline \multicolumn{1}{c}{ Alternative } & \multicolumn{1}{c}{ Result } \\
\hline Leave as is. & $\begin{array}{l}\text { Drawings show the discharge line to be cut and capped approximately } \\
50 \text {-ft south of the tank. The cell where the inlet lines originate was } \\
\text { sealed and a new concrete floor poured over the access plug when } \\
\text { operations were discontinued in the building. No contamination can } \\
\text { likely enter the tank through its engineered system piping. Risk from } \\
\text { the tank has been shown to be below the EPA target risk range and } \\
\text { does not exceed a } 10^{-6} \text { risk level. }\end{array}$ \\
Cut and cap inlet and & $\begin{array}{l}\text { Drawings show the outlet line to be cut and capped now. Cutting and } \\
\text { off-gas vent lines. }\end{array}$ \\
capping the inlet and off-gas vent lines would not significantly reduce \\
the probability of liquid entering the tank because the cell where the \\
inlet piping originates is sealed and contains no source of liquid. Risk \\
from the tank would not be increased by selection of this alternative, \\
but any further risk reduction it provides would require careful cost \\
justification. \\
Removing the tank would totally eliminate any future risk from the \\
tank.
\end{tabular}

\subsubsection{Summary}

Field investigation shows that the cell beneath Building 3013 that contains the inlet drains to this tank has been sealed. Before the building was turned over to the Chemical Technology Division, the floor of Building $\mathbf{3 0 1 3}$ was scarified and a new layer of concrete put down that effectively sealed the access plug to the cell. This new floor surface was covered with a waterproof coating. Thus, there is every indication that the tank is secure from receiving input through the engineered inlet piping system. The tank was emptied in 1993 and when examined again in January 1995 was found to contain liquid. The facility manager for the tanks suspects that the liquid is rain water or surface runoff that entered the tank through deteriorated gaskets 
in the flanged connections on top of the tank or through the gasketed connection of the top itself. The tank could be either left as is because the risk has been shown to be below the EPA target risk range and does not exceed a $10^{-6}$ risk level, or the tank could be removed if the cost of removal can be justified. EPA and TDEC have agreed that this tank does not need to be remediated through the CERCLA process.

\subsection{TANK SYSTEM T-30}

\subsubsection{Description}

Tank T-30 is an $~ 825-\mathrm{gaT}$ tank located in a concrete vault south of Building 4507. System piping (see Fig. 4) consists of a 1-in. stainless steel drain line from Building 4507, a 2-in. stainless steel overflow line, and a 1/2-in. stainless steel steam jet discharge line.

\subsubsection{Current Status}

Tank T-30 is categorized as an industrial facility (see footnote 1). The tank was emptied in 1993. Field investigations of the tank in March 1995 have been hampered by both fixed and loose contamination within the tank vault. The tank's level instrumentation indicates that the tank has remained empty. Table 5 shows the alternative actions for Tank T-30.

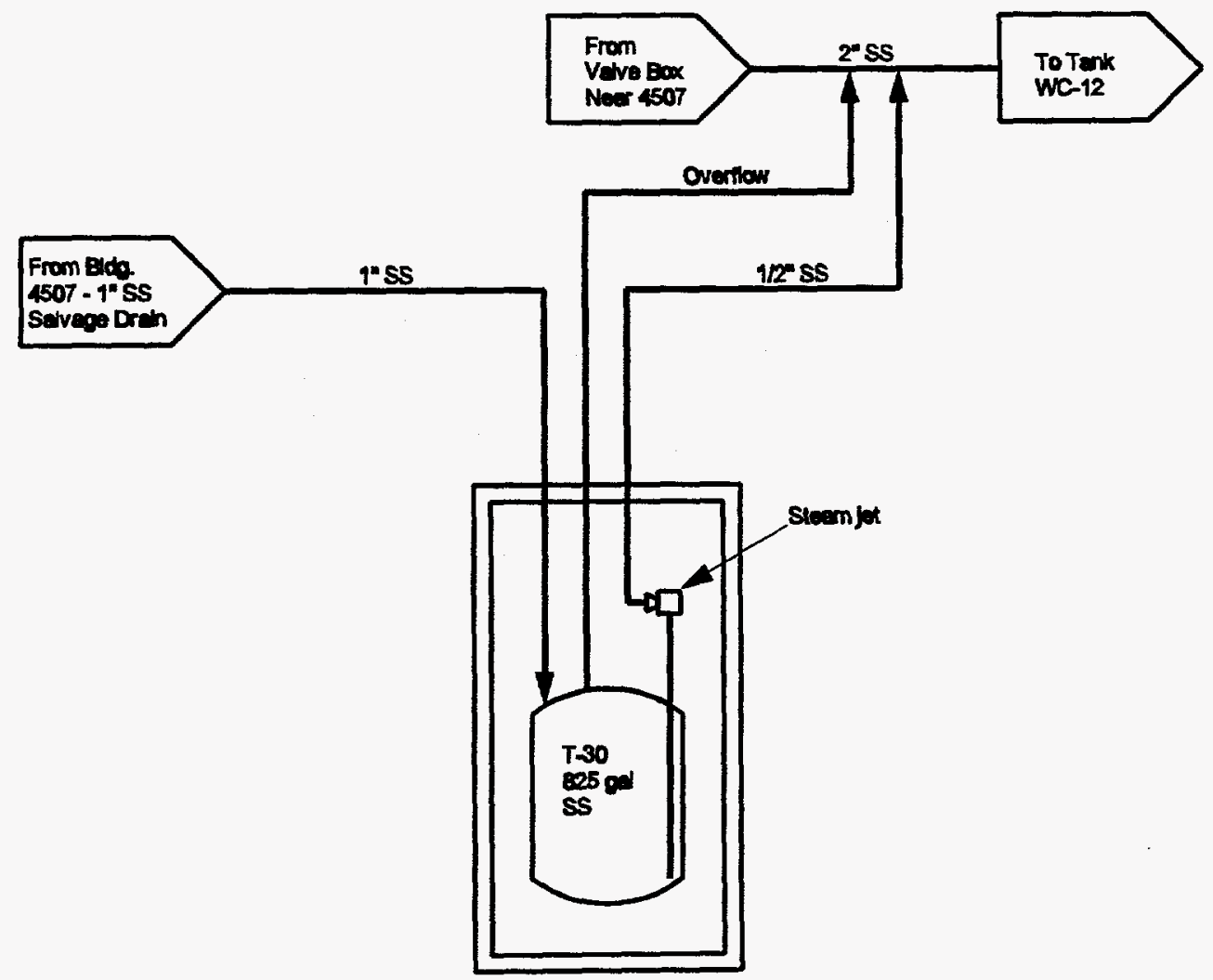

Fig. 4. Tank T-30. 
Table 5. Alternative actions for Tank T-30

\begin{tabular}{|c|c|}
\hline Alterative & Result \\
\hline Leave as is. & $\begin{array}{l}\text { Risk from the tank has been shown to be below the EPA target } \\
\text { risk range. }\end{array}$ \\
\hline $\begin{array}{l}\text { Cut and cap inlet and outlet } \\
\text { lines. }\end{array}$ & $\begin{array}{l}\text { Cutting and capping the inlet line would reduce the probability } \\
\text { of liquid entering the tank. Cutting and capping the outlet line } \\
\text { and the overflow line would reduce the unlikely probability of } \\
\text { liquid backing up through discharge piping. Risk from the tank } \\
\text { would not be increased by selection of this alternative, but any } \\
\text { further risk reduction it provides would require careful cost } \\
\text { justification. }\end{array}$ \\
\hline Remove tank. & $\begin{array}{l}\text { Removing the tank would totally eliminate any future risk from } \\
\text { the tank. }\end{array}$ \\
\hline Fill tank ith grout. & $\begin{array}{l}\text { Risk from the tank would not be increased by selection of this } \\
\text { alternative, but any further risk reduction it provides would } \\
\text { require careful cost justification. Filling the tank with grout } \\
\text { would be detrimental if, in the future, a decision is made to } \\
\text { remove the tank as part of an overall site remedial action. }\end{array}$ \\
\hline
\end{tabular}

\subsubsection{Summary}

Because of its location in a vault, little chance exists for ground or surface water to infiltrate into the tank. A remote possibility exists that back flow from the discharge header to the WC-10 tank farm could enter tank T-30 through the tank discharge or overflow lines. For this reason, consideration should be given to isolating the discharge and overflow lines from T-30. If this alternative is chosen, the inlet line should also be cut and capped within the tank vault. This would involve little additional expense and would ensure that the tank and its associated piping, thus secured from the probability of receiving further contamination and having been shown to pose no unacceptable risk, could be left in place until final remedial action is accomplished for Building 4507 and the surrounding area or until the tank could be removed and disposed of if economically feasible. Either alternative involving isolation or removal of the tank would require some decontamination of the tank and the tank vault. EPA and TDEC have agreed that this tank need not be remediated through the CERCLA process. 


\section{DISTRIBUTION}

1. J. Baxter

2. C. A. Bednarz

3. A. E. Blocher

4. H. L. Boston

5. W. D. Brickeen

6. C. Clark

7. M. Clauberg

8. T. J. Cofer

9. J. S. Davidson

10. K. L. Deroos

11. C. H. Dukes

12. S. B. Garland

13. D. L. Garrett

14. J. T. Etheridge

15. H. K. Hepworth

16. L. Holder

17. J. H. Hooyman

18. L. L. Kaiser

19. C. Mims

20-21. P. T. Owen

22. K. Rice

23. R. G. Ross, Jr.

24. C. B. Scott

25. C. Shipp

26. P. A. Schrandt

27. A. Smith

28-29. D. K. Stair

30. W. T. Thompson

31. S. D. Van Hoesen

32. M. L. Whitehead

33. R. C. Williams

34. P. S. Wood

35. ORNL Patent Section

36. Central Research Library

37-39. ER Document Management Center

40-42. ORNL ER Document Management

43. ORNL Laboratory Records

44. J. T. Sweeny, DOE Oak Ridge Operations Office, P.O. Box 2001, Oak Ridge, Tennessee 37831

45. Office of Assistant Manager for Energy Research and Development, DOE Oak Ridge Operations Office, P.O. Box 2001, Oak Ridge, Tennessee 37831

46-47. Office of Scientific and Technical Information, P.O. Box 62, Oak Ridge, Tennessee 